\title{
DEVELOPMENT OF BLAST RESISTANT SOMACLONES OF THE UPLAND RICE CULTIVAR ARAGUAIA ${ }^{1}$
}

\author{
LEILA GARCÊS DE ARAÚJO² ${ }^{2}$ ANNE SITARAMA PRABHU³ ${ }^{3}$ and ADELSON DE BARROS FREIRE ${ }^{4}$
}

\begin{abstract}
The degree of blast resistance of upland rice (Oryza sativa L.) cultivar Araguaia has decreased over time causing significant yield losses. The major objective of this study was to obtain blast (Pyricularia grisea) resistant somaclones, adapting greenhouse and field selection procedures. Rice blast resistance and agronomic traits were assessed in $\mathrm{R}_{2}$ to $\mathrm{R}_{6}$ generations derived from regenerant plants $\left(R_{1}\right)$ from immature panicles of Araguaia. The evaluation and selection procedures include testing of early segregating populations and fixed lines in the advanced generations, under natural field conditions, and artificial inoculations in the greenhouse, with prevalent races IB-1 and IB-9 of $P$. grisea. Somaclones with both vertical resistance and slow blasting resistance were obtained. Twenty of 31 somaclones developed with a high degree of vertical resistance and fan shaped plant type maintained resistance in field and blast nursery tests in the $\mathrm{R}_{6}$ generation. Greenhouse selection with two specific physiologic races yielded 44 somaclones with slow blasting resistance, similar plant type and yield potential as that of Araguaia.
\end{abstract}

Index terms: Oryza sativa, Pyricularia grisea, somaclonal variation, tissue culture.

\section{DESENVOLVIMENTO DE SOMACLONES DA CULTIVAR ARAGUAIA RESISTENTES À BRUSONE EM ARROZ DE SEQUEIRO}

\begin{abstract}
RESUMO - O grau de resistência à brusone da cultivar de arroz (Oryza sativa) Araguaia tem decrescido ao longo dos anos, resultando em prejuízos significativos na produtividade. O objetivo principal deste estudo foi obter somaclones resistentes à brusone (Pyricularia grisea), adaptando os métodos de seleção em casa de vegetação e de campo. Foram avaliadas plantas regeneradas $\left(\mathrm{R}_{1}\right)$ de panículas imaturas da cultivar Araguaia nas gerações $\mathrm{R}_{2}$ a $\mathrm{R}_{6}$ para resistência à brusone e características agronômicas. O método de avaliação e seleção de plantas envolveu avaliações de populações segregantes e linhagens fixadas, em condições naturais de infecção no campo, e infecções artificiais em casa de vegetação com duas raças prevalecentes de $P$. grisea IB-1 e IB-9. Foram obtidos somaclones com resistência vertical e progresso lento de brusone. Vinte de 31 somaclones desenvolvidos com alto grau de resistência vertical e tipo de planta em leque apresentaram estabilidade da resistência no campo e nos viveiros de brusone na geração $\mathrm{R}_{6}$. No procedimento de seleção em casa de vegetação com duas raças específicas, foram obtidos 44 somaclones com progresso lento de brusone, as quais não diferiram da Araguaia quanto ao tipo de planta e potencial de produtividade.
\end{abstract}

Termos para indexação: Oryza sativa, Pyricularia grisea, variação somaclonal, cultura de tecido.

\footnotetext{
${ }^{1}$ Accepted for publication on May 20, 1999.

2 Agronomist, M.Sc., Embrapa-Centro Nacional de Pesquisa de Arroz e Feijão (CNPAF), Caixa Postal 179, CEP 74001-970 St. Antônio de Goiás, GO. CNPq Scholar. E-mail: leilag@enpaf.embrapa.br

${ }^{3}$ Biologist, Ph.D., Embrapa-CNPAF.

${ }^{4}$ Agronomist, M.Sc., Embrapa-CNPAF.
}

\section{INTRODUCTION}

Araguaia is one of the first upland rice cultivars developed for blast (Pyricularia grisea (Cooke) Sacc.) resistance for cultivation in west-central Brazil. It was originated from a cross between a local susceptible cultivar, IAC 47 , and a blast resistant 
line, TOS 2578/7-4-2-3-B2, introduced from Nigeria. Araguaia exhibited moderate resistance to leaf blast and a high degree of panicle blast resistance in the field, when it was released, in 1986. However, disease susceptibility of Araguaia increased over the years, resulting in significant grain yield losses. Improvement of Araguaia for blast resistance has been one of the research goals of Embrapa-Centro Nacional de Pesquisa de Arroz e Feijão (CNPAF) because of its high yield potential. Rapid progress in incorporating blast resistance into upland rice cultivars by conventional breeding procedures has often been hindered by the high degree of grain discoloration of the exotic blast resistant gene sources.

Cell culture is one of the alternatives for inducing resistance to diseases in susceptible cultivars which are well adapted to local soil and climatic conditions. The artificial culture medium generates a high frequency of stable and heritable variants for different traits, including disease resistance, which can be utilized in crop improvement (Larkin \& Scowcroft, 1981; Daub, 1986; Illg, 1990; Mandal et al., 1995). This genetic variation produced in tissue culture, termed somaclonal variation has been reported in many crop species (Larkin \& Scowcroft, 1981). Somaclones resistant to Fiji virus, Helminthosporium sacchari in sugar cane, Helminthosporium maydis in corn, Phytophthora infestans in potato, Fusarium oxysporum f. lycopersici in tomato and Fusarium oxysporum f. medicaginis in alfalfa have been reported (Daub, 1986). In most of these cases the resistance of somaclones was expressed under field conditions and utilized for breeding purposes. Studies on somaclonal variation for resistance to sheath blight (Thanatephorus cucumeris) have shown that unselected variation in vitro also constitutes an excellent source of novel disease resistance (Xie et al., 1990). Two somaclones resistant to sheath blight, LSBR-33 and LSBR-5 have been selected from the susceptible rice cultivar Labelle (Xie et al., 1990). However, the information on somaclonal variation for blast resistance is scanty. According to Pachon (1989), there was no variation for blast resistance in somaclones. On the other hand, Bouharmont et al. (1991) obtained $R_{2}$ lines resistant to blast from the calli derived from mature embryos. Studies conducted in Louisiana, USA, have shown that the resistance of somaclones of the irrigated rice cultivar, Newbonnet was not high (Rush et al., 1992). In Brazil, a high degree of partial resistance has been reported in progenies of regenerated plants derived from immature panicles of a susceptible upland rice cultivar IAC 47 (Araújo et al., 1997). These discrepancies may be partly attributed to the test conditions and disease pressure under which the somaclones were assessed, and the nature of resistance. Also, various other factors may affect somaclonal variation such as genotype, explant source, composition of the culture medium, and time of cultivation (Evans et al., 1984). Genetic variation in regenerated plants has been reported to result from both pre-existing variation in the explant donor tissue, as well as variation induced by cell culture. These alterations in the genome have been attributed to expression of mutant cells in explant, mitotic crossing over, and cytological changes (Evans et al., 1984).

The studies on somaclonal variation may permit accomplishment of breeding objectives in relation to rapid development of blast resistant lines from existing commercial susceptible rice cultivars.

The major objective of the present study was to induce blast resistance in rice cultivar Araguaia, adapting both greenhouse and field selection procedures.

\section{MATERIAL AND METHODS}

\section{Induction of callus and regeneration of plants}

Immature panicles $1-4 \mathrm{~cm}$ long, showing white to yellow spikelets, have been employed to initiate calli and regeneration of plants of rice cultivar Araguaia in the tissue culture laboratory of Embrapa-CNPAF according to Xie et al. (1990). The plantlets were directly transplanted to pots containing $6 \mathrm{~kg}$ of soil and were grown to maturity under greenhouse conditions. The regenerated plants are referred to as $R_{1}$ generation and the subsequent generations as $\mathrm{R}_{2}, \mathrm{R}_{3}$ etc., according to the nomenclature of Yurkova et al. (1982). The outline of the procedure adapted to develop blast resistant somaclones is shown on the next page: 


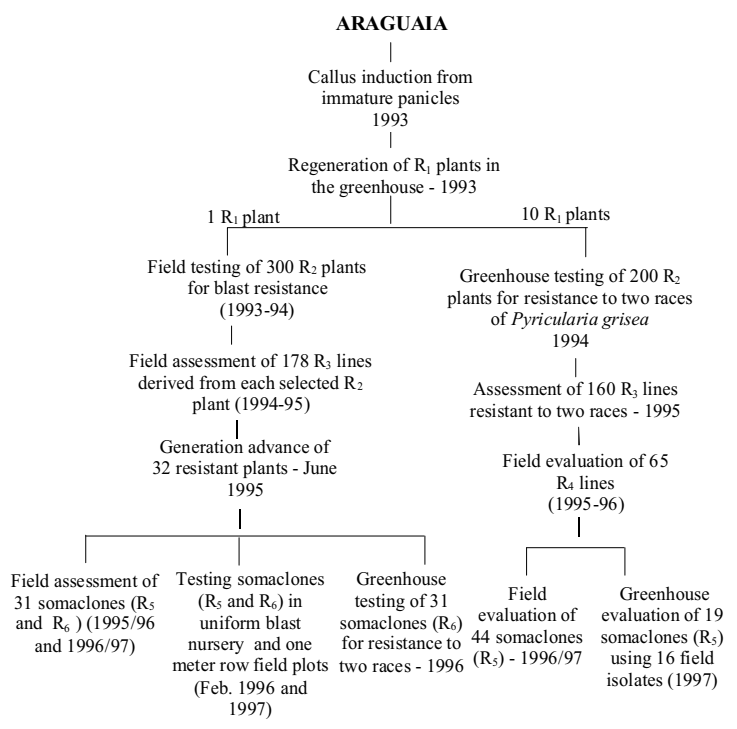

\section{Greenhouse experiments}

The bulk $\mathrm{R}_{2}$ population was composed of 200 plants derived from 20 seeds from each of the $10 \mathrm{R}_{1}$ plants. Plants were grown in plastic trays $(30 \times 10 \times 15 \mathrm{~cm})$ containing $6 \mathrm{~kg}$ of soil fertilized with $5 \mathrm{~g}$ of NPK (4-30-16), $1 \mathrm{~g}$ of zinc sulphate and $2 \mathrm{~g}$ of ammonium sulphate at planting. Top dressing was done with $2 \mathrm{~g}$ of ammonium sulphate per tray, 20 days after planting. Ten to eleven seeds were sown in ten rows and later thinned to ten plants per row, maintaining 100 plants per tray.

Single conidial isolate T1 was established from leaf lesions of cultivar Tetep (race IB-1) at St. Antonio de Goiás, Goiás State, Brazil, in 1990, and isolate ECJ 5 P1-88 (race IB-9) was obtained from infected panicles of cultivar Guarani grown in the experimental fields in Jaciara, Mato Grosso State, in 1988. Physiologic races in upland rice were earlier established based on the reaction on eight standard international differentials, the predominant ones being IB-1, IB-9, IB-13 ande IB-41 (Filippi \& Prabhu, 1996). The physiologic races IB-1 and IB-9 were utilized for the inoculation tests because they were widely prevalent under upland conditions.

Inoculations were performed by spraying aqueous spore suspension, using De Vilbiss №15 connected to a compressor maintaining uniform pressure (Prabhu et al., 1992). Disease was evaluated seven to nine days after inoculation based on a visual rating scale. In this study the disease severity ratings 0 and 1 represented complete or vertical resistance and 3, 5, 7 and 9, susceptible reaction.
Seedlings showing susceptible reaction to race IB-1 were removed from the trays and the remaining resistant seedlings, showing 0 -1 reaction, were inoculated with isolate ECJ 5 P1-88 when most of the seedlings had reached the fourth leaf stage. Seedlings resistant to both races were transplanted to pots containing $6 \mathrm{~kg}$ of soil for harvesting the seed.

Seeds were collected from self-pollinated individual $\mathrm{R}_{2}$ resistant plants for evaluation of $160 \mathrm{R} 3$ lines. Ten rows of somaclones one each per $10 \mathrm{~cm}$ long row were planted in plastic trays. Inoculation and evaluation of $\mathrm{R}_{3}$ lines were made on 21-day-old plants with the two races IB-1 and IB-9, according to the same procedure described for $\mathrm{R}_{2}$ seedlings. The resistant plants selected at random, totaling 65 , were transplanted to pots containing $6 \mathrm{~kg}$ of soil and self fertilized to produce seed.

The $65 \mathrm{R}_{4}$ lines derived from individual $\mathrm{R}_{3}$ plants resistant to both races were assessed for leaf blast in the field. Seed was sown in $1.0 \mathrm{~m}$ long single rows spaced $0.30 \mathrm{~m}$ apart. One row of Araguaia was interspersed after every $10 \mathrm{R}_{4}$ lines. A three row spreader strip with a mixture of susceptible cultivars such as IRAT 112, IAC 47, IAC 25 and IAC 165 were maintained perpendicular to test rows on both sides.

The $\mathrm{R}_{5}$ progeny derived from bulk seed harvest from $\mathrm{R}_{4}$ was handled in two ways as shown in the outline of the scheme illustrated in Material and Methods. Forty-four somaclones, including 38 with leaf blast rating 3 , two with rating 5 (SC 41 and SC 42) and two with rating 7 (SC 43 and $\mathrm{SC} 44$ ) in the $\mathrm{R}_{4}$ generation, were assessed in the field, during 1996/97 in an augmented complete block design layout (Federer, 1956). Somaclones were planted in five blocks, each consisting of eight somaclones and five controls (Araguaia, two somaclones with leaf blast rating 3 and two somaclones with rating 7), totaling 13 treatments. Plots consisted of three $2.0 \mathrm{~m}$ long rows, spaced $0.30 \mathrm{~m}$ apart. Five plants were selected at random, in the central row of each plot to assess the incidence of leaf blast based on percentage of leaves with sporulating lesions. Leaf blast severity was assessed on three fully expanded leaves based on a 10-grade scale according to Notteghem (1981). Five serial observations on leaf blast were made at 7-day intervals to plot the disease progress curves. The area under disease progress curve (AUDPC) was calculated for each treatment according to Shaner \& Finney (1977). Log transformation helped to reduce the heterogeneity of error mean square because of the observed association between mean and standard deviation. Analysis of variance (ANOVA) was done on the transformed values. The logit $\left[\log _{e}(Y) /(1-Y)\right]$ of proportion of leaf blast severity was regressed on time, in days, to estimate the apparent infec- 
tion rate (slope of the regression line) for each somaclone. Coefficient of determination was used to test the goodness of fit of regression lines. Significant differences in slopes of disease curves between somaclone and cultivar Araguaia were tested by t-test, according to Snedecor \& Cochran (1978). The agronomic characteristics evaluated included plant height, panicle length, grain number per panicle, filled grain weight per panicle. Plant height measurements were based on one plant in the central row, whereas the other three components were assessed from a random sample of three panicles. In addition, the yield potential of somaclones was assessed based on grain weight of 100 panicles. The seed harvested from individual $R_{4}$ plants constituted the $\mathrm{R}_{5}$ lines for the greenhouse testing.

Nineteen somaclones, including 15 with leaf blast rating 3, two with rating 5 (SC 03 and SC 04) and two with rating 7 (SC 02 and $\mathrm{SC} 05$ ) in the $\mathrm{R}_{4}$ field assessment, were evaluated for leaf blast under artificial inoculation conditions. Inoculations were done with 16 isolates collected from $\mathrm{R}_{4}$ lines in the field. These included five isolates from cultivar Araguaia, 10 isolates from somaclones showing leaf blast rating 3 and one original isolate ECJ5 $\mathrm{P}^{1}-88(I B-9)$. The experiment had three replications. Also, eight international differentials were planted in a tray and inoculated along with the somaclones to identify the physiologic races and observe the disease pressure under which the inoculations were conducted. The maximum disease rating in all three replications was considered.

\section{Field experiments}

The $R_{2}$ population was grown in the field plots at the Embrapa-CNPAF, in St. Antonio de Goiás, Goiás State, Brazil, during the 1993-94 rice growing season. The soil at the experimental site was Dark-Red Latosol according to the Brazilian classification system which is equivalent to an Oxisol in the USA soil taxonomy. The climate according to the classification of Köppen is Aw of tropical savanna. Three hundred $R_{2}$ plants derived from seeds harvested from one individual self-pollinated $\mathrm{R}_{1}$ plant, regenerated in the greenhouse, were evaluated for blast resistance along with Araguaia. The plots, consisting of 10 rows $1.0 \mathrm{~m}$ long and spaced $30 \mathrm{~cm}$ between rows were established in three replications. A plant population of 100 plants per plot was maintained. A three row spreader strip with a mixture of susceptible cultivars (IRAT 112, IAC 47, IAC 25, Dourado precoce) was established perpendicular to the rows of the plots, 30 days prior to planting. All plots were fertilized at the rate of $250 \mathrm{~kg} \mathrm{ha}^{-1}(4-30-16)$ NPK and 125 of $\mathrm{N}$ in the form of ammonium sulphate and $20 \mathrm{~kg} \mathrm{ha}^{-1}$ of zinc sulphate at planting. An additional
$20 \mathrm{~kg} \mathrm{ha}^{-1}$ of $\mathrm{N}$, in the form of ammonium sulphate, was applied as top dressing at the maximum tillering stage.

Leaf blast was assessed 67 days after sowing according to a visual rating scale of 0 to 9 , where 0 and 1 represent a complete or vertical resistance, and 3 to 9 susceptible reaction (International Rice Research Institute, 1988). Panicle blast was evaluated 10 days before harvesting on individual plants according to a scale based on incidence of panicle or neck blast $(0=$ no incidence, $1=1-5 \%$, $3=6-12 \%, 5=13-25 \%, 7=26-50 \%$ and $9 \geq 50 \%$ infected panicles). At maturity, the height of the tallest tiller in the plant was measured on 50 plants at random per plot, totaling 150 plants in three replications. Height measurements on control plots was based on a total of 15 plants. In addition, observations were made on flowering and plant type. One hundred and twenty-eight plants were selected on the basis of resistance to leaf and panicle blast for further evaluation in the next generation.

The $\mathrm{R}_{3}$ population, totaling 178 somaclones derived from individual $R_{2}$ plants, was grown in the field during 1994-95. Each plot consisted of two rows of $2 \mathrm{~m}$ length, spaced $0.35 \mathrm{~m}$ apart, and sown at the rate of 60 seeds per meter in December 1994. Two rows of Araguaia were interspersed after every 20 rows of somaclones. The test plots were fertilized at the rate of $400 \mathrm{~kg} \mathrm{ha}^{-1}$ of ammonium sulphate to induce high disease susceptibility. A border with spreader rows was maintained perpendicular to the test rows as in the case of the $R_{2}$ population assessment. In addition to leaf, and panicle blast and plant height measurements, observations were made after harvesting, on panicle length, grain weight and grain number per panicle. Panicle length, grain weight and grain number per panicle were determined based on two panicles of the selected plant. Seed was harvested from one individual plant from each somaclone. The total number of $178 \mathrm{R}_{3}$ plants were reduced to 31 on the basis of grain type, sterility and other yield components.

The $\mathrm{R}_{4}$ generation was advanced by multiplying the seed collected from single $R_{3}$ plants, in $2 \mathrm{~m}$ rows under irrigated conditions in June, 1995. The bulk harvest of the seed was based on $20 \mathrm{R}_{4}$ plants of each somaclone.

The $\mathrm{R}_{5}$ generation was handled in four separate ways. One part of the seeds was planted in a field experiment, conducted in January 1996, to assess blast resistance and other agronomic traits in a randomized complete block design with three replications. The plots consisted of five $4 \mathrm{~m}$ rows spaced $0.35 \mathrm{~m}$ apart and seeded at 80 seeds $\mathrm{m}^{-1}$. Treatments included 31 somaclones and Araguaia (control). Disease and height measurements were taken as in the $\mathrm{R}_{3}$ population assessment. The grain yield in $\mathrm{kg} \mathrm{ha}^{-1}$, adjusted to $13 \%$ moisture, was based on the seed har- 
vested from the three central rows of $3.0 \mathrm{~m}$ length. The mean panicle length determination were based on a sample of three panicles selected at random from the three central rows. The grain number, filled grain percentage, 100 grain weight were based on a sample of eight panicles from three central rows. Grain weight of 100 panicles was used as one of the measures of grain yield. After threshing, head yield measurements were taken based on a $100 \mathrm{~g}$ of grain per sample.

These somaclones were simultaneously tested in the field in one meter long row plots. To obtain severe disease incidence, spreader rows with susceptible cultivars were established perpendicular to the rows on both sides. The cultivar Araguaia was included after every 10 somaclones as a control.

In addition to the yield trial, the 31 somaclones were assessed for leaf blast in a uniform rice blast nursery under a heavy disease pressure, in two different locations in the State of Goiás at Palmital and Capivara experimental stations, in the month of February, 1996. Disease evaluations were made 34 days after planting at Capivara and 45 days after planting at Palmital based on the 0-9 scale (International Rice Research Institute, 1988).

The somaclones were also evaluated in the greenhouse under artificial inoculation conditions, using the same procedure adapted for the $\mathrm{R}_{2}$ and $\mathrm{R}_{3}$ lines. Inoculation tests of the 31 somaclones were done separately with races IB- 1 and IB-9, as described in the greenhouse experiments.

The $\mathrm{R}_{6}$ somaclones were produced from the bulk harvest of $\mathrm{R}_{5}$ lines. A field experiment was conducted during 1996/97 to assess blast resistance and agronomic characteristics of the 31 somaclones. The layout, plot size, cultural practices and parameters of evaluation were the same as described for the $R_{5}$ field experiment. A combined analysis of variance was conducted for all yield components, in addition to the correlation among yield and yield components.

Finally, the same 31 somaclones were tested for leaf blast in a uniform rice blast nursery at Palmital and Capivara in February, 1997. Leaf blast reaction was assessed as described earlier for blast nursery evaluation of the $\mathrm{R}_{5}$ lines.

\section{RESULTS AND DISCUSSION}

The induction of callus from immature panicles initiated after six days of in vitro culture. These results agree with those obtained previously by $\mathrm{Wu} \&$ Zapata (1992) for other rice cultivars. The maximum proliferation of callus occurred between the third and the fourth weeks resulting in a mean frequency of $75 \%$ induction. Root formation and shoot growth of the seedlings, in the regeneration culture medium began 10 to 15 and 15 to 20 days of culture, respectively. The mean frequency of plant regeneration was $11.8 \%$. The occurrence of albinos was not observed, possibly due to the explant source. The primary regenerated plants $\left(R_{1}\right)$ transplanted to pots in the greenhouse were all fertile and did not differ in plant type from the control parent Araguaia.

\section{Greenhouse experiments}

Two hundred $\mathrm{R}_{2}$ plants derived from $10 \mathrm{R}_{1}$ plants showed complete resistance to two distinct physiologic races, IB-1 and IB-9, under artificial inoculation tests. No segregation of plants for resistance and susceptibility was observed in the progeny, whereas Araguaia exhibited susceptibility to race IB-9 and resistant reaction to IB-1 under similar conditions. One hundred and sixty $\mathrm{R}_{3}$ lines derived from the individual $R_{2}$ plants were assessed in the greenhouse for resistance to two races IB-1 and IB-9. The $\mathrm{R}_{3}$ lines did not segregate for either of the races.

Sixty five $\mathrm{R}_{4}$ lines resistant to races IB-1 and IB-9 were assessed, under field conditions, for leaf and panicle blast. All $\mathrm{R}_{4}$ lines showed different degrees of susceptibility, varying from 3 to 7 , while cultivar Araguaia exhibited susceptible reaction 7 , indicating the prevalence of matching virulence in the field population of $P$. grisea to the resistance genes in the somaclones.

Leaf blast incidence and area under disease progress of 44 selected $R_{5}$ somaclones were compared with cultivar Araguaia under field conditions (Table 1). Both incidence and AUDPC of somaclones were relatively lower than that obtained for Araguaia, although statistically not significant. The correlation between incidence and AUDPC was positive and highly significant $(\mathrm{r}=0.78, \mathrm{P}=0.001)$. The apparent infection rates of the majority of somaclones differed significantly from Araguaia, according to the t-test. The slow disease progress curves of two somaclones, SC 02 and SC 03 were compared with cultivar Araguaia as illustrated in Fig. 1. The selection with two races in earlier generations, $\mathrm{R}_{2}$ and $\mathrm{R}_{3}$, had some effect in reducing the disease levels under natural field conditions. 
TABLE 1. Incidence of leaf blast, area under the disease progress curve, apparent infection rate and correlation coefficients in the $R_{5}$ somaclones of Araguaia (1995/96).

\begin{tabular}{|c|c|c|c|c|}
\hline Genotype & $\begin{array}{c}\text { Leaf blast incidence } \\
\qquad(\%)\end{array}$ & $\begin{array}{c}\text { Area under disease } \\
\text { progress curve (AUDPC) }\end{array}$ & $\begin{array}{l}\text { Apparent infection } \\
\text { rate }^{1}\end{array}$ & $\begin{array}{c}\text { Coefficient of } \\
\text { determination (r) }\end{array}$ \\
\hline Araguaia (control) & 42.2 & 162.42 & 0.0023 & 0.94 \\
\hline SC01 (control) & 23.1 & 68.27 & $0.0001 * *$ & - \\
\hline SC02 (control) & 5.31 & 41.1 & $0.0006^{* *}$ & - \\
\hline SC03 (control) & 7.8 & 37.01 & $0.0005 * *$ & - \\
\hline SC04 (control) & 11.1 & 39.9 & $0.0006^{* *}$ & - \\
\hline $\mathrm{SC} 05$ & 8.81 & 51.57 & 0.0005 & 0.59 \\
\hline $\mathrm{SC} 06$ & 4.41 & 39.74 & $0.0006^{* *}$ & - \\
\hline $\mathrm{SC} 07$ & 2.21 & 23.77 & $0.0004 * *$ & - \\
\hline $\mathrm{SC} 08$ & 13.31 & 35.6 & $0.0004^{* *}$ & - \\
\hline $\mathrm{SC} 09$ & 8.81 & 56.6 & $0.0009 * *$ & - \\
\hline $\mathrm{SC} 10$ & 2.21 & 21.52 & $0.0003 * *$ & - \\
\hline $\mathrm{SC} 11$ & 2.21 & 21.62 & $0.0003 * *$ & - \\
\hline $\mathrm{SC} 12$ & 13.31 & 54.85 & $0.0009 * *$ & - \\
\hline $\mathrm{SC} 13$ & 13.31 & 40.96 & 0.0004 & 0.68 \\
\hline $\mathrm{SC} 14$ & 6.65 & 39.6 & 0.0005 & 0.77 \\
\hline $\mathrm{SC} 15$ & 20.01 & 54.85 & 0.0007 & 0.80 \\
\hline $\mathrm{SC} 16$ & 22.21 & 43.11 & 0.0004 & 0.71 \\
\hline $\mathrm{SC} 17$ & 8.83 & 49.5 & 0.0007 & 0.79 \\
\hline $\mathrm{SC} 18$ & 11.11 & 29.43 & 0.0003 & 0.80 \\
\hline SC19 & 15.51 & 42.76 & 0.0005 & 0.80 \\
\hline $\mathrm{SC} 20$ & 24.41 & 63.54 & 0.0007 & 0.70 \\
\hline $\mathrm{SC} 21$ & 15.51 & 41.28 & 0.0004 & 0.74 \\
\hline $\mathrm{SC} 22$ & 28.81 & 54.91 & 0.0005 & 0.58 \\
\hline $\mathrm{SC} 23$ & 13.31 & 40.7 & 0.0005 & 0.86 \\
\hline $\mathrm{SC} 24$ & 4.41 & 43.0 & $0.0005^{* *}$ & - \\
\hline $\mathrm{SC} 25$ & 6.61 & 33.9 & 0.0004 & 0.86 \\
\hline $\mathrm{SC} 26$ & 24.41 & 75.4 & 0.0009 & 0.75 \\
\hline $\mathrm{SC} 27$ & 20.01 & 52.9 & 0.0006 & 0.81 \\
\hline $\mathrm{SC} 28$ & 20.01 & 37.5 & $0.0004 * *$ & - \\
\hline SC29 & 6.61 & 50.13 & $0.0007^{* *}$ & - \\
\hline $\mathrm{SC} 30$ & 22.21 & 94.55 & $0.0014^{* *}$ & - \\
\hline SC31 & 0.01 & 25.13 & 0.0005 & 0.67 \\
\hline $\mathrm{SC} 32$ & 13.31 & 59.25 & $0.0009 * *$ & - \\
\hline $\mathrm{SC} 33$ & 8.81 & 39.74 & 0.0006 & 0.86 \\
\hline $\mathrm{SC} 34$ & 6.61 & 37.05 & $0.0005^{* *}$ & - \\
\hline SC35 & 17.71 & 67.13 & $0.0011 * *$ & - \\
\hline SC36 & 0.01 & 34.0 & 0.0007 & 0.70 \\
\hline SC37 & 20.01 & 48.62 & $0.0006^{* *}$ & - \\
\hline $\mathrm{SC} 38$ & 13.31 & 42.6 & $0.0006^{* *}$ & - \\
\hline SC39 & 13.31 & 54.16 & $0.0009 * *$ & - \\
\hline $\mathrm{SC} 40$ & 13.31 & 56.12 & $0.0009^{* *}$ & - \\
\hline $\mathrm{SC} 41$ & 17.71 & 81.52 & $0.0001^{* *}$ & - \\
\hline $\mathrm{SC} 42$ & 33.31 & 78.52 & $0.0012 * *$ & - \\
\hline $\mathrm{SC} 43$ & 6.61 & 49.17 & $0.0009 * *$ & - \\
\hline $\mathrm{SC} 44$ & 42.21 & 237.36 & 0.0037 & 0.83 \\
\hline
\end{tabular}

${ }^{1}$ Mean infection rates followed by asterisks differ significantly from the cultivar Araguaia according to t-test at the 0.001 probability level; the infection rates with significant $r$ values were considered for $t$-test. 
Somaclones did not show statistically significant differences in plant height, panicle length, grain number per panicle and filled grain per panicle. However, two out of 44 somaclones showed significantly negative values of 100 panicle grain weight when compared to control parental cultivar Araguaia.

Nineteen randomly selected somaclones were analyzed for differential reaction to 16 different isolates of $P$. grisea. Disease ratings of somaclones were lower when compared to Araguaia except for one isolate, SC 07, which showed rating 5 for Araguaia as well as for the somaclones. Differential interactions between isolates and somaclones were observed in 10 out of 16 isolates analyzed. The high leaf blast ratings of eight international differentials indicated the disease pressure under which the tests were conducted. All isolates belong to race IB-9, which is one of the most predominant races affecting upland rice cultivars.

\section{Field assessment}

A high degree of blast resistance was observed in the plant population, whereas the control plants of Araguaia showed susceptible reaction to leaf and panicle blast under field conditions. The $\mathrm{R}_{2}$ plant population was highly uniform for the characteristic fan shaped plant type which is different from the erect type of Araguaia. The distribution of plant height in the $\mathrm{R}_{2}$ population was broad, ranging from 45 to $75 \mathrm{~cm}$ in height, in relation to Araguaia, which skewed to the right, with plant heights ranging from

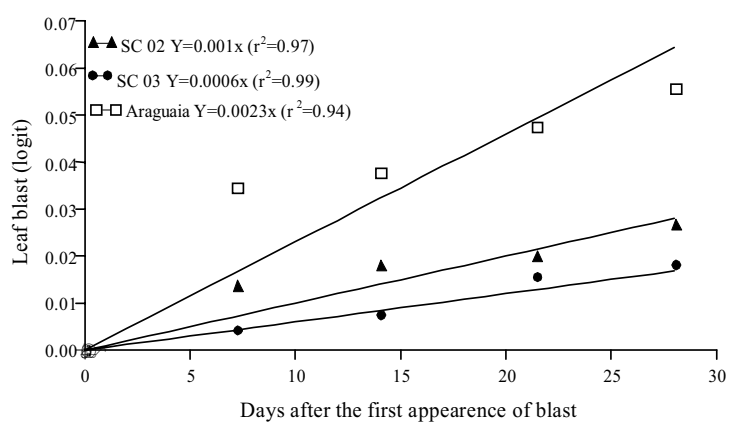

FIG. 1. Leaf blast progress in somaclones (SC 02 and $\mathbf{S C} 03$ ) in $\mathbf{R}_{5}$ generation and cultivar Araguaia (control) under field conditions.
65 to $75 \mathrm{~cm}$. The $\mathrm{R}_{2}$ plants utilized for evaluation for blast resistance were relatively small, as compared to a segregating $\mathrm{F}_{2}$ population, in conventional breeding. The main source of variation was one regenerant $\mathrm{R}_{1}$ plant which gave rise to the $\mathrm{R}_{2}$ population. There was no apparent variation among $\mathrm{R}_{2}$ plants, except for blast resistance, plant type and height, indicating that the major phenotypic variation or mutations observed among $\mathrm{R}_{2}$ plants possibly occurred during the course of callus induction or regeneration. Four mutations, for early heading, albino, short culm, and sterility were obtained in the progenies of 12 rice plants regenerated from a single callus of rice seed. These mutations have been considered to be accumulated in growing calli and or regenerating plants (Fukui, 1983).

The $\mathrm{R}_{3}$ lines were uniform in the field, with few exceptions maintaining the blast resistance and plant type. However, continuous variation was observed in plant height, panicle length, grain weight and grain number per panicle. Plant height in $\mathrm{R}_{3}$ showed wide distribution, ranging from 55 to $95 \mathrm{~cm}$, as compared to the 85 to $100 \mathrm{~cm}$ range of Araguaia. The correlation between $R_{2}$ and $R_{3}$ progeny for height was positive and significant $(\mathrm{r}=0.42, \mathrm{P}=0.001)$. The frequency distribution of data for panicle length, grain weight and grain number per panicle is shown in Fig. 2. In general, the distribution of the data for regenerated plants was wider than that of control plants of Araguaia, with some extreme values for panicle length. The higher values observed for grain weight and grain number, in some clones, than in the case of cultivar Araguaia, has potential agronomic importance.

$\mathrm{R}_{3}$ plants were harvested individually and the generations advanced by sowing as separate $\mathrm{R}_{4}$ lines in the mid season. The $\mathrm{R}_{4}$ lines were uniform and fertile.

In the field trial conducted with 31 somaclones, the leaf and panicle blast resistance and plant type showed high stability in $\mathrm{R}_{5}$ generation. Somaclones did not differ significantly from Araguaia in plant height and 100 grain weight. However, significant differences were observed among somaclones for panicle length, grain number/panicle, filled grain/panicle, 100 panicle grain weight, and grain yield. The overall performance of somaclones in the 
$\mathrm{R}_{5}$ generation for yield and yield components was similar or inferior to Araguaia. Artificial inoculation tests of the 31 somaclones with the races IB-1 and IB-9 showed a high degree of leaf blast resistance.

The results of a field experiment with 31 somaclones were similar to those obtained for the $\mathrm{R}_{5}$ generation. The leaf and panicle blast resistance, as well as fan shaped plant type, were maintained. The analysis of variance showed no significant differences for the agronomic characteristics analyzed.

The data on combined analysis of $\mathrm{R}_{5}$ and $\mathrm{R}_{6}$ field trials are presented in Table 2. Differences were not detected for filled grains per panicle and panicle length. A majority of somaclones did not differ from Araguaia, while few of them showed inferior values of hundred panicle grain weight and grain yield. Variation in height among somaclones ranged from 76 to $103 \mathrm{~cm}$, whereas for Araguaia the height was $95 \mathrm{~cm}$. Somaclone SC 31 had significantly less grain weight than Araguaia, and coincidentally, showed poor per-
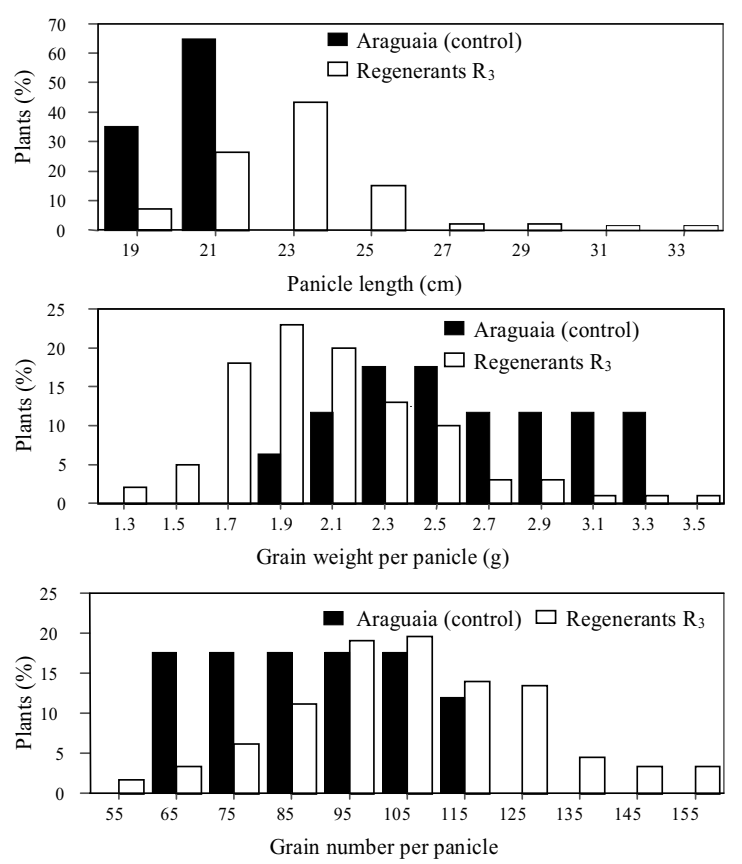

FIG. 2. Frequency distribution of plants according to panicle length, grain weight per panicle and grain number per panicle. formance in yield and 100 panicle grain weight. All somaclones were highly resistant to blast and, with few exceptions, inferior to Araguaia for other traits in a population as small as that studied here.

Most of the correlation among agronomic characteristics of $R_{5}$ and $R_{6}$ lines were positive, and highly significant (Table 3 ). Grain yield was correlated with height, 100 panicle weight, 100 grain weight, filled grains and grain number per panicle.

Field and blast nursery assessments of $R_{5}$ and $R_{6}$ lines for leaf blast were made during 1995/96 and 1996/97, respectively. While a majority of somaclones showed resistant reaction in all three tests a few such as $\mathrm{SC} 02, \mathrm{SC} 03, \mathrm{SC} 07, \mathrm{SC} 09$, SC12, SC17, SC19, SC23, SC31 exhibited differential reactions, indicating possible differences among somaclones in genes controlling leaf blast resistance.

One of the main purposes of this study was to obtain somaclones with a high degree of vertical resistance by evaluation and selection of lines from $\mathrm{R}_{2}$ to $\mathrm{R}_{6}$, under natural field conditions and somaclones with adequate partial resistance by artificial inoculation tests of lines with two widely prevalent races under controlled greenhouse condition. The $R_{2}$ plant population derived from one $R_{1}$ plant selected at random, became highly resistant under field conditions. Plants expressing mutation for vertical resistance also had fan shaped plant type. Further genetic analysis of plant type and resistance is underway and will be published elsewhere. Not all $\mathrm{R}_{2}$ populations derived from the same explant source showed similar alterations. The erect plant type in the $R_{2}$ progeny derived from the $10 R_{1}$ plants showed susceptible reaction in the field. However, the leaf blast severity of some of these somaclones as measured by the rate of disease increase was much lower than cultivar Araguaia and probably possess some level of partial or slow blasting resistance. The somaclones $\left(R_{2}\right.$ and $\left.R_{3}\right)$ with erect plant type showed complete resistance to the races IB-1 and IB-9 in the greenhouse. Inoculation tests of 19 somaclones $\left(\mathrm{R}_{5}\right)$ with 16 isolates pertaining to race IB-9 showed differential interaction between isolates and somaclones. However the disease ratings were lower compared to the cultivar Araguaia. Further studies are required to determine the degree of partial resistance of these somaclones by inoculating with an 
isolate such as SC 41 virulent to all somaclones. Panicle blast incidence was low and did not differ among somaclones and has little value as a selection parameter.

The advance of generation utilizing the field selection procedure maintained resistance, resulting in 20 somaclones. The method of selection done in the greenhouse with two physiologic races of $P$. grisea in the early generations resulted 44 somaclones with slow blasting resistance. The results in the present study have shown that it is possible to obtain effec- tive resistance through somaculture from susceptible rice cultivars. Thus, undesirable traits associated with resistant donors of exotic or non-agronomic types in the conventional crosses can be avoided. The adaptation of available tissue culture techniques will also reduce the time required by the conventional breeding process, besides overcoming undesirable agronomic characters (Zapata et al., 1995). The high frequency of desirable agronomic types, combined with blast resistance, can be attributed to the use of Araguaia as a starting parental material, as

TABLE 2. Plant height, panicle length, grain number per panicle, filled grain per panicle, 100 grain weight, 100 panicle grain weight and grain yield of somaclones of Araguaia (1995/96 and 1996/97) ${ }^{1}$.

\begin{tabular}{|c|c|c|c|c|c|c|c|}
\hline Somaclones & $\begin{array}{l}\text { Height } \\
(\mathrm{cm})\end{array}$ & $\begin{array}{c}\text { Panicle } \\
\text { lenght }(\mathrm{cm})\end{array}$ & $\begin{array}{l}\text { Grain number } \\
\text { per panicle }\end{array}$ & $\begin{array}{l}\text { Filled grain } \\
\text { per panicle }\end{array}$ & $\begin{array}{l}100 \text { grain } \\
\text { weight }(\mathrm{g})\end{array}$ & $\begin{array}{l}100 \text { panicle/ } \\
\text { grain weight }(\mathrm{g})\end{array}$ & $\begin{array}{l}\text { Grain yield } \\
\left(\mathrm{kg} \mathrm{ha}^{-1}\right)^{2}\end{array}$ \\
\hline SC01 & $76.3 \mathrm{~b}$ & $22.1 \mathrm{a}$ & $90.5 \mathrm{ab}$ & $51.7 \mathrm{a}$ & $2.5 \mathrm{ab}$ & $106.6 \mathrm{abc}$ & $1,558.1 \mathrm{abcd}$ \\
\hline $\mathrm{SC} 02$ & $92.2 \mathrm{ab}$ & $20.9 \mathrm{a}$ & $80.5 \mathrm{ab}$ & $46.5 \mathrm{a}$ & $2.3 \mathrm{ab}$ & $91.2 \mathrm{abc}$ & $1,217.6 \mathrm{abcd}$ \\
\hline $\mathrm{SC} 03$ & $93.8 \mathrm{ab}$ & $21.8 \mathrm{a}$ & $82.4 \mathrm{ab}$ & $47.5 \mathrm{a}$ & $2.4 \mathrm{ab}$ & $87.4 \mathrm{abc}$ & $1,252.6 \mathrm{abcd}$ \\
\hline $\mathrm{SC} 04$ & $105.4 \mathrm{a}$ & $22.9 \mathrm{a}$ & $85.6 \mathrm{ab}$ & $54.1 \mathrm{a}$ & $2.4 \mathrm{ab}$ & $85.9 \mathrm{abc}$ & $1,448.8 \mathrm{abcd}$ \\
\hline $\mathrm{SC} 05$ & $97.7 \mathrm{a}$ & $23.0 \mathrm{a}$ & $76.1 \mathrm{ab}$ & $46.5 \mathrm{a}$ & $2.5 \mathrm{ab}$ & $86.4 \mathrm{abc}$ & 1,417.3abcd \\
\hline SC06 & $92.5 \mathrm{ab}$ & $22.2 \mathrm{a}$ & $76.5 \mathrm{ab}$ & $50.4 a$ & $2.3 \mathrm{ab}$ & $87.2 \mathrm{abc}$ & $1,539.4 \mathrm{abcd}$ \\
\hline SC07 & $97.6 \mathrm{a}$ & $21.9 \mathrm{a}$ & $58.8 \mathrm{~b}$ & $47.6 \mathrm{a}$ & $2.4 \mathrm{ab}$ & $86.0 \mathrm{abc}$ & $1,564.3 \mathrm{abcd}$ \\
\hline SC08 & $97.2 \mathrm{ab}$ & $22.5 \mathrm{a}$ & $80.8 \mathrm{ab}$ & $49.1 \mathrm{a}$ & $2.3 \mathrm{ab}$ & $91.5 \mathrm{abc}$ & $1,333.7 \mathrm{abcd}$ \\
\hline SC09 & $103.0 \mathrm{a}$ & $22.5 \mathrm{a}$ & $102.4 \mathrm{a}$ & $52.0 \mathrm{a}$ & $2.3 \mathrm{ab}$ & $96.3 \mathrm{abc}$ & $1,841.8 \mathrm{abc}$ \\
\hline $\mathrm{SC} 10$ & $89.8 \mathrm{ab}$ & $22.1 \mathrm{a}$ & $89.5 \mathrm{ab}$ & $53.2 \mathrm{a}$ & $2.3 \mathrm{ab}$ & $91.5 \mathrm{abc}$ & $1,430.6 \mathrm{abcd}$ \\
\hline SC11 & $93.9 \mathrm{ab}$ & $22.1 \mathrm{a}$ & $94.5 \mathrm{ab}$ & $45.8 \mathrm{a}$ & $2.4 \mathrm{ab}$ & $75.2 \mathrm{abc}$ & $880.6 \mathrm{~d}$ \\
\hline $\mathrm{SC} 12$ & $98.0 \mathrm{a}$ & $23.0 \mathrm{a}$ & $86.3 \mathrm{ab}$ & $53.0 \mathrm{a}$ & $2.3 \mathrm{ab}$ & $101.7 \mathrm{abc}$ & 1,498.1 abcd \\
\hline $\mathrm{SC} 13$ & $95.1 \mathrm{ab}$ & $22.2 \mathrm{a}$ & $85.2 \mathrm{ab}$ & $52.4 \mathrm{a}$ & $2.2 \mathrm{~b}$ & $93.4 \mathrm{abc}$ & $1,262.2 \mathrm{abcd}$ \\
\hline $\mathrm{SC} 14$ & $97.6 \mathrm{ab}$ & $22.1 \mathrm{a}$ & $82.8 \mathrm{ab}$ & $51.2 \mathrm{a}$ & $2.3 \mathrm{ab}$ & $101.3 \mathrm{abc}$ & $1,458.5 \mathrm{abcd}$ \\
\hline $\mathrm{SC} 15$ & $97.7 \mathrm{ab}$ & $21.9 \mathrm{a}$ & $75.4 \mathrm{ab}$ & $51.0 \mathrm{a}$ & $2.4 \mathrm{ab}$ & $83.2 \mathrm{bc}$ & $1,167.8 \mathrm{abcd}$ \\
\hline $\mathrm{SC} 16$ & $93.1 \mathrm{ab}$ & $21.2 \mathrm{a}$ & $95.5 \mathrm{ab}$ & $54.4 \mathrm{a}$ & $2.6 \mathrm{a}$ & $101.4 \mathrm{abc}$ & 1,216.1 abcd \\
\hline SC17 & $103.9 \mathrm{a}$ & $22.3 \mathrm{a}$ & $108.3 a$ & $54.7 \mathrm{a}$ & $2.3 \mathrm{ab}$ & $125.0 \mathrm{abc}$ & $1,697.5 \mathrm{abcd}$ \\
\hline SC18 & $89.0 \mathrm{ab}$ & $21.1 \mathrm{a}$ & $81.7 \mathrm{ab}$ & $52.3 \mathrm{a}$ & $2.4 \mathrm{ab}$ & 82.9 bc & $1,561.5 \mathrm{abcd}$ \\
\hline SC19 & $93.8 \mathrm{ab}$ & $23.2 \mathrm{a}$ & $98.5 \mathrm{a}$ & $49.7 \mathrm{a}$ & $2.5 \mathrm{ab}$ & $96.2 \mathrm{abc}$ & $987.0 \mathrm{~cd}$ \\
\hline $\mathrm{SC} 20$ & $95.1 \mathrm{ab}$ & $20.6 \mathrm{a}$ & $93.7 \mathrm{ab}$ & $53.8 \mathrm{a}$ & $2.4 \mathrm{ab}$ & $116.2 \mathrm{abc}$ & 1,641.1 abcd \\
\hline SC21 & $91.4 \mathrm{ab}$ & $20.4 \mathrm{a}$ & $88.9 \mathrm{ab}$ & $46.7 \mathrm{a}$ & $2.4 \mathrm{ab}$ & $86.1 \mathrm{abc}$ & $1,212.6 \mathrm{abcd}$ \\
\hline $\mathrm{SC} 22$ & $90.8 \mathrm{ab}$ & $21.2 \mathrm{a}$ & $78.1 \mathrm{ab}$ & $54.0 \mathrm{a}$ & $2.3 \mathrm{ab}$ & $83.5 \mathrm{bc}$ & $1,436.0 \mathrm{abcd}$ \\
\hline $\mathrm{SC} 23$ & $102.0 \mathrm{a}$ & $23.2 \mathrm{a}$ & $97.1 \mathrm{ab}$ & $59.5 \mathrm{a}$ & $2.6 \mathrm{a}$ & $118.3 \mathrm{ab}$ & $1,575.4 \mathrm{abcd}$ \\
\hline $\mathrm{SC} 24$ & $94.8 \mathrm{ab}$ & $21.5 \mathrm{a}$ & $101.8 \mathrm{a}$ & $54.9 \mathrm{a}$ & $2.4 \mathrm{ab}$ & $112.4 \mathrm{abc}$ & $1,152.4 \mathrm{abcd}$ \\
\hline $\mathrm{SC} 25$ & $97.1 \mathrm{ab}$ & $22.3 \mathrm{a}$ & $84.8 \mathrm{ab}$ & $47.8 \mathrm{a}$ & $2.4 \mathrm{ab}$ & $101.5 \mathrm{abc}$ & 1,524.6abcd \\
\hline $\mathrm{SC} 26$ & $93.8 \mathrm{ab}$ & $20.8 \mathrm{a}$ & $78.8 \mathrm{ab}$ & $43.9 \mathrm{a}$ & $2.3 \mathrm{ab}$ & $95.2 \mathrm{abc}$ & $1,236.8 \mathrm{abcd}$ \\
\hline $\mathrm{SC} 27$ & $103.6 \mathrm{a}$ & $21.5 \mathrm{a}$ & $104.3 \mathrm{a}$ & $58.9 \mathrm{a}$ & $2.5 \mathrm{ab}$ & $128.1 \mathrm{a}$ & $2,043.6 \mathrm{a}$ \\
\hline $\mathrm{SC} 28$ & $92.9 \mathrm{ab}$ & $25.6 \mathrm{a}$ & $89.3 \mathrm{ab}$ & $43.4 \mathrm{a}$ & $2.4 \mathrm{ab}$ & $94.3 \mathrm{abc}$ & $1,119.9 \mathrm{bcd}$ \\
\hline SC29 & $92.1 \mathrm{ab}$ & $21.1 \mathrm{a}$ & $91.5 \mathrm{ab}$ & $50.5 \mathrm{a}$ & $2.3 \mathrm{ab}$ & $96.8 \mathrm{abc}$ & $1,176.7 \mathrm{abcd}$ \\
\hline SC30 & 91.9ab & $22.2 \mathrm{a}$ & $87.0 \mathrm{ab}$ & $45.3 \mathrm{a}$ & $2.3 \mathrm{ab}$ & 96.1 abc & $1,008.8 \mathrm{~cd}$ \\
\hline SC31 & $92.6 \mathrm{ab}$ & $21.7 \mathrm{a}$ & $96.7 \mathrm{ab}$ & $46.2 \mathrm{a}$ & $1.8 \mathrm{c}$ & $102.1 \mathrm{ab}$ & $892.3 d$ \\
\hline Araguaia & $95.3 \mathrm{ab}$ & $22.2 \mathrm{a}$ & $89.3 \mathrm{ab}$ & $60.3 \mathrm{a}$ & $2.5 \mathrm{ab}$ & $120.8 \mathrm{ab}$ & $1,972.4 \mathrm{ab}$ \\
\hline
\end{tabular}

${ }^{1}$ Means followed by the same letter in a column do not differ significantly according to Tukey's test at the 0.05 probability level.

2 Means are based on pooled data of $R_{5}$ and $R_{6}$ lines in field experiments during 1995/96 and 1996/97. 
TABLE 3. Correlation coefficients (r) for agronomic characters in somaclones of Araguaia (1995/96 and 1996/97) ${ }^{1}$.

\begin{tabular}{lccccccc}
\hline Parameters & $\mathrm{Ht}$ & $\mathrm{Pl}$ & $\mathrm{GNP}$ & $\mathrm{FGP}$ & $100 \mathrm{GW}$ & $100 \mathrm{PGW}$ & $\mathrm{GY}$ \\
\hline Plant height (Ht) & & $0.314^{* *}$ & $0.243^{* *}$ & $0.321^{* *}$ & $0.261^{* *}$ & $0.314^{* *}$ & $0.449^{* *}$ \\
Panicle length (Pl) & & -- & $0.031 \mathrm{~ns}$ & $0.011 \mathrm{~ns}$ & $0.043 \mathrm{~ns}$ & $0.027 \mathrm{~ns}$ & $0.012 \mathrm{~ns}$ \\
Grain number per panicle (GNP) & & & -- & $0.554^{* *}$ & $0.515^{* *}$ & $0.616^{* *}$ & $0.489^{* *}$ \\
Filled grains per panicle (FGP) & & & & -- & $0.740^{* *}$ & $0.829^{* *}$ & $0.817^{* *}$ \\
100 grain weight (100 GW) & & & & & -- & $0.446^{* *}$ & $0.424^{* *}$ \\
100 panicle grain weight (100 PGW) & & & & & -- & $0.703^{* *}$ \\
Grain yield (GY) & & & & & -- \\
\hline
\end{tabular}

${ }^{1}$ Number of observations utilized in the analysis $(n=192)$, except for grain yield, where $n=160$.

** Significant at $\mathrm{P} \leq 0.01$.

well as the short period of callus induction in the culture medium.

\section{CONCLUSIONS}

1. The results show that induced variation includes vertical and slow blasting resistance.

2. Somaclones are not significantly different from the cultivar Araguaia for most of the agronomic traits except for blast resistance and plant type.

3. The somaclones of Araguaia can serve as novel resistance gene sources for upland rice improvement.

4. Short term objectives of inducing resistance in susceptible rice cultivars, well adapted to local conditions, can be accomplished by callus cultures.

\section{ACKNOWLEDGEMENTS}

To Dr. Josias Correa de Faria and Dr. Ricardo Silva Araujo for critically going through the manuscript, and Dr. Francisco J.P. Zimmermann for his help with statistical analyses. This study was partly funded by CNPq.

\section{REFERENCES}

ARAÚJO, L.G.; PRABHU, A.S.; FREIRE, A.B. Variação somaclonal na cultivar de arroz IAC-47 para resistência à brusone. Fitopatologia Brasileira, Brasília, v.22, n.2, p.125-130, 1997.

BOUHARMONT, J.; DEKEYSER, A.; SINT JAN, V. van; DOGBE, Y.S. Application of somaclonal varia- tion and in vitro selection to rice improvement. In: INTERNATIONAL RICE RESEARCH INSTITUTE (Manila, Filipinas). Rice genetics II. Manila, 1991. p.271-277.

DAUB, M.E. Tissue culture and the selection of resistance to pathogens. Annual Review of Phytopathology, Palo Alto, v.24, p.159-186, 1986.

EVANS, D.A.; SHARP, W.R.; MEDINA-FILHO, H.P. Somaclonal and gametoclonal variation. American Journal of Botany, Columbus, v.71, n.6, p.759-774, 1984.

FEDERER, W.T. Augmented designs. Hawaiian Planters' Record, Aiea, v.55, n.2, p.191-208, 1956.

FILIPPI, M.C.; PRABHU, A.S. Inheritance of blast resistance in rice to two Pyricularia grisea races, IB-1 and IB-9. Brazilian Journal of Genetics, Ribeirão Preto, v.19, p.599-604, 1996.

FUKUI, K. Sequential occurrence of mutation in a growing rice callus. Theoretical and Applied Genetics, Berlin, v.65, p.225-230, 1983.

ILLG, R.D. Variação somaclonal. In: TORRES, A.C.; CALDAS, L.S. (Eds.). Técnicas e aplicações da cultura de tecidos de plantas. Brasília : Associação Brasileira de Cultura de Tecidos de Plantas/Embrapa-CNPH, 1990. p.287-295.

INTERNATIONAL RICE RESEARCH INSTITUTE (Los Baños, Filipinas). Standard evaluation system for rice. 3.ed. Los Baños, 1988. 54p.

LARKIN P.J.; SCOWCROFT, W.R. Somaclonal variation a novel source of variability from cell cultures for 
plant improvement. Theoretical and Applied Genetics, Berlin, v.60, p.197-214, 1981.

MANDAL, A.B.; ANSARI, M.M.; SHARMA, T.V.R.S.; BANDYOPADHYAY, A.K. Somaclonal variation for disease resistance in indica rice. Rice Biotechnology Quarterly, Rock Hill, v.23, p.8-9, 1995.

NOTTEGHEM, J.L. Cooperative experiment on horizontal resistance to rice blast. In: INTERNATIONAL RICE RESEARCH INSTITUTE (Los Baños, Filipinas). Blast and upland rice: report and recommendations from the meeting for international collaboration in upland rice improvement. Los Baños, 1981. p.43-51.

PACHON, J.G. Evaluación del uso potencial de la variación somaclonal en el mejoramiento de algunos caracteres de importancia económica en el arroz (Oryza sativa L.). Bogotá : Pontificia Universidad Javeriana, 1989. 94p.

PRABHU, A.S.; FILIPPI, M.C.; CASTRO, N. Pathogenic variation among isolates of Pyricularia oryzae affecting rice, wheat and grasses in Brazil. Tropical Pest Management, Basingstoke, v.38, n.4, p.367371, 1992.

RUSH, M.C.; SEILHAN, K.P.; LINSCOMBE, S.D.; OARD, J.; XIE, Q.J. Use of somaclonal variation for improved disease resistance in rice. Louisiana State University. Agricultural Center. Rice Re- search Station. Annual Research Report, v.84, p.349-360, 1992.

SHANER, G.; FINNEY, R.E. The effect of nitrogen fertilization on the expression of slow-mildewing resistance in Knox wheat. Phytopathology, Saint Paul, v.67, n.8, p.1051-1056, 1977.

SNEDECOR, G.W.; COCHRAN, W.G. Statistical methods. 6.ed. Ames : Iowa State University Press, 1978. 592p.

WU, C.; ZAPATA, F.J. Plant regeneration from protoplasts isolated from primary callus of four japonica rice (Oryza sativa L.) varieties. Plant Science, Limerick, v.86, p.83-87, 1992.

XIE, Q.J.; RUSH, M.C.; CAO, J. Somaclonal variation for disease resistance in rice (Oryza sativa L.). In: GRAYSON, B.T.; GREEN, M.B.; COPPING, L.G. (Eds.). Pest management on rice. London : Elsevier Applied Science, 1990. p.491-509.

YURKOVA, G.N.; LEVENKO, B.A.; NOVOZHJLOV, P.V. Plant regeneration in wheat tissue culture. Biochemie und Physiologie der Pflanzen, Jena, v.177, p.337-344, 1982.

ZAPATA, F.J.; TORRIZO, L.B.; ANDO, A. Current developments in plant biotechnology for genetic improvement: the case of rice (Oryza sativa L.). World Journal of Microbiology \& Biotechnology, Oxford, v.11, p.393-399, 1995. 